\title{
GÊNERO E DIVISÃO SEXUAL DO TRABALHO NO BRASIL'1
}

\author{
GENDER AND SEXUAL DIVISION OF LABOR IN BRAZIL
}

\author{
Nanci Stancki Silva? \\ Leda Maria Caira Gitahy ${ }^{3}$
}

\begin{abstract}
Resumo
Este artigo trata das mudanças e permanências nas formas de organização do trabalho num contexto "globalizado" e seus reflexos sobre a divisão sexual do trabalho no Brasil. Discute a interferência da construção social do masculino e do feminino nas distinções entre atividades de homens e de mulheres, ou seja, na criação e recriação permanentemente da divisão sexual do trabalho. Analisa, ainda, as transformações do mundo do trabalho, ressaltando a heterogeneidade desse espaço, e como os modelos de produção se apropriam das diferenças de gênero, transformando-as em desigualdades (salariais, de acesso ao emprego e promoção, por exemplo). A revisăo de um conjunto de pesquisas sobre gênero e trabalho no Brasil pretende proporcionar elementos para reflexäo sobre a articulação entre gênero e as mudanças e permanências observadas no mercado de trabalho brasileiro.
\end{abstract}

Palavras-chave: Gênero, divisão sexual do trabalho e globalização

\begin{abstract}
This essay is about changes and permanencies in the ways of organization of labor in a global context and its reflexes on the sexual division of labor in Brazil. It debates the social construction interference of male and female difference among their activities. Or in other words, it is about the permanent creation and recreation of sexual labor division. It still analyzes the transformations of the labor universe, emphasizing the heterogeneity of that space and as the production models take advantage of sexual differences transforming them in imparities (as far as wages and employment access is concerned). A review of a set of surveys about sexes and labor in Brazil aims at providing elements for reflection about the management between them and the changes and permanencies observed on Brazilian labor market.
\end{abstract}

Keywords: Gender, sexual labor division and globalization

\section{A construção das diferenças de gênero}

O conceito de gênero busca estabelecer a distinção entre o sexo biológico e a construção social do masculino e do feminino, conceitos elaborados de modo relacional, inseridos em contextos específicos e permeados por relações de poder.

A análise da realidade, numa perspectiva de gênero, não nega as diferenças biológicas entre homens e mulheres, mas consideram-nas como insuficientes para definir um ser humano, pois "a humanidade não é uma espécie 
animal, é uma realidade histórica" (BEAUVOIR, 1949: p. 73), colocando-nos a necessidade de compreensão da construção social do masculino/feminino e das identidades de gênero. Tais construções não são fixas, pois diferentes sociedades ou períodos históricos podem entender o significado de ser homem ou ser mulher de forma diversa.

Destacamos que as diferenças de gênero são construidas numa sociedade marcada por relaçôes de poder sexualizadas e, nesse sentido, Scott (1995) traz importante contribuição ao articular gênero e poder. Para a autora, gênero é um elemento constitutivo de relações sociais baseadas nas diferenças percebidas entre os sexos, uma forma primária de dar significado às relações de poder que implica quatro elementos que se interrelacionam:

a) os simbolos culturalmente disponíveis que evocam representações que, com freqüência, são contraditórias;

b) os conceitos normativos que expressam interpretações dos significados dos simbolos que tentam limitar e conter suas possibilidades metafóricas. Esses conceitos tomam a forma típica de uma oposição binária fixa que afirma, de maneira categórica e inequivoca, o significado do homem e da mulher, do masculino e do feminino;

c) a noção de fixidez e a natureza do debate ou da representação que leva à aparência de uma permanência atemporal na representação binária do gênero. Essa discussão deve incluir uma concepção de politica, bem como uma referência às instituições e à organização social;

d) a identidade subjetiva que coloca a necessidade de examinar as formas pelas quais as identidades generificadas são construidas e relacionar seus achados com toda uma série de atividades, de organizações e representações sociais historicamente especificas.

Adivisão sexual do trabalho insere-se nas relações de poder sexualizadas e se manifesta por meio da distribuição das atividades entre homens e mulheres de forma desigual, seja no âmbito da produção ou da reprodução. A legitimação desse processo passa pela construção de identidades sociais masculinas e femininas em consonância com o que se espera de cada um dos sexos no contexto em que se inserem.

Para Carneiro (1994), na cultura ocidental, a identidade é construida, pressupondo o outro, ou seja, a feminina explicita-se na diferenciação com a masculina. E, segundo Saffioti (1987), as identidades sociais são construídas por meio da atribuição de responsabilidades distintas para homens e mulheres, como, por exemplo, a tarefa de socialização dos filhos que é tradicionalmente atribuida às mulheres, independente da origem de classe ou etnia. Mesmo quando a mulher desempenha uma atividade remunerada fora do lar, permanece vista como a principal responsável pela preparação das gerações mais jovens para a vida adulta.

Bruschini (1995) observa que na sociedade brasileira predominam relações assimétricas e hierárquicas expressas em posições desiguais de um e de outro sexo tanto na esfera da produção, quanto no âmbito privado das relações familiares. A autora afirma que, apesar das transformações do 
mundo moderno, às mulheres cabem as atividades reprodutivas, enquanto aos homens cabe o papel de provedor familiar. As responsabilidades masculinas e femininas no âmbito familiar têm conseqüências distintas para um ou outro sexo no mercado de trabalho. A participação dos homens nesse mercado decorre das oportunidades oferecidas pelo mercado de trabalho, pouco interferindo os fatores familiares e domésticos na determinação da ocupação masculina. O trabalho produtivo é parte inerente e inquestionável da sua identidade, construida em torno da função social de provedor.

Para a mesma autora, a identidade feminina, por outro lado, é construida em torno do mundo privado e da manutenção de um modelo de família em que elas têm as responsabilidades domésticas e socializadoras, isso condiciona a participação da mulher no mercado de trabalho. Mesmo que a necessidade econômica familiar e a existência de empregos sejam fatores fundamentais para a entrada da mulher no mercado de trabalho, a constante necessidade de articular atividades domésticas e profissionais limita a disponibilidade feminina para o trabalho que passa a depender de uma complexa combinação de características pessoais e familiares. O estado conjugal, a presença de filhos, a idade, a escolaridade, bem como as caracteristicas do grupo familiar (familia em formação, maduras ou mais velhas; presença de filhos pequenos ou adolescentes, etc.) e a estrutura familiar (familia conjugal, chefiada por mulher, ampliada pela presença de outros parentes, etc.) são fatores que estão sempre presentes na decisão das mulheres de ingressar ou permanecer no mercado de trabalho.

\section{Globalização, gênero e trabalho}

O processo de globalização tem transformado intensamente o mundo do trabalho, acentuando a sua heterogeneidade. Segundo Hirata (2002), a globalização significa interdependência de mercados e não homogeneização do trabalho e, se os fluxos financeiros desconhecem fronteiras e trabalham no imediatismo, a desigualdade das situações sociais e de trabalho, segundo países, sexos, raças e gerações, persiste e pode inclusive aumentar.

Nesse sentido é importante analisar o papel das relações de gênero na construção de novas desigualdades. Sagasti (1995) reforça a tese de ampliação da heterogeneidade, alertando que a globalização não ocorre de forma integrada, aprofunda diferenças tanto entre paises quanto entre pessoas de um mesmo país e contribui para a restrição do acesso a direitos básicos de uma parcela significativa da população mundial.

Para Chesnais (1996), esse processo pode ser associado à redução do dinamismo da economia norte-americana - final da década de 1960 que motivou a emergência de politicas econômicas baseadas na liberalização e desregulamentação, buscando reduzir o grau de intervencionismo nos mercados, eliminar barreiras e fronteiras que pudessem impedir a concorrência e a recuperação da economia americana. Grandes industriais japoneses passaram a usar essa expressão para definir um mundo "triádico" emergente, no qual eles se unem com europeus e americanos numa mútua cooperação 
em defesa de seus interesses econômicos. A globalização, dessa forma, pode ser vista como uma fase especifica de um processo de internacionalização e valorização do capital em regiões do mundo onde há recursos ou mercados. Esse processo ocorreu pari passu ao avanço tecnológico em duas áreas chaves: comunicação e informação (processamento de dados). A redução do tempo e dos custos envolvidos nas comunicações foi condição sine qua non para a globalização e sua crescente necessidade de transmissão de informaçōes. Assim, essas tecnologias se constituíram tanto em condição permissiva quanto em fator de intensificação desse processo.

Entre as caracteristicas da globalização, destacam-se: tendência de organização dos grupos industriais em "empresas-rede"; surgimento de oligopólios mundiais num número crescente de indústrias que delimitam entre si um espaço privilegiado de concorrência e cooperação; aumento do grau de interpenetração entre os capitais de diferentes nacionalidades; aumento da importância dos fluxos de investimentos externos, permitindo que boa parte das ações e decisões vinculadas aos processos de produção e distribuição ocorram mais no interior das empresas globais e dependam menos dos vínculos locais entre empresas nacionais; permanente processo de exclusão de paises e grupos sociais (CHESNAIS, 1996).

Para Frigotto (1998), as formas de exclusão se sustentam por uma ideologia neoliberal, manifestada em politicas dos organismos internacionais que, representando o grande capital, ditam estratégias que afirmam a nova era do mercado e do ajuste dentro de uma hegemonia conservadora. Entre essas estratégias aparecem a desregulamentação, a descentralização e a privatização. A desregulamentação, do ponto de vista social, representa a supressão de leis, normas e regulamentos que asseguram direitos. Assim, direitos passam a ser vistos como inibidores das leis naturais do mercado, justificando a precarização do trabalho.

Ao final da década de 1970, estratégias empresariais deram à globalização um caráter microeconômico, e um "novo" padrão de acumulação capitalista passa a propagar a necessidade de uma organização de trabalho mais flexivel. A partir desse processo, emergem diferentes interpretações acerca do que tem ocorrido com o trabalho que tanto pode ser visto como continuidade quanto como uma ruptura do modelo taylorista/fordista

Para Larangeira (1999), numa perspectiva de esgotamento e superação do modelo fordista, os mercados não estariam mais aceitando a padronização, exigindo produtos diferenciados de acordo com demandas de segmentos sócioculturais. As empresas deveriam ser flexíveis e capazes de responder às mudanças do mercado, utilizando-se, para isso, de novas tecnologias e novas formas de gestão da força de trabalho (trabalho em equipe e círculos de controle de qualidade, com ênfase na cooperação, na multifuncionalidade e na polivalência). O "novo" trabalhador deveria ser mais qualificado, flexível e envolvido com a produção.

Todavia, essa visão de superação do modelo fordista pode ser contestada, por exemplo, pelos teóricos da Escola Francesa da Regulação ${ }^{4}$ que consideram os processos de transformação da economia numa perspectiva da acumulação do capital. Para eles, as alterações no modelo resultariam na incapacidade para 
enfrentar, através de ganhos de produtividade, a crise do sistema capitalista. Isso teria imposto às empresas a necessidade de reestruturação econômica, de introdução de novas tecnologias, de flexibilidade dos processos de produção e gestão e alteração dos produtos. Entretanto, os novos modelos de produção (a especialização flexivel, por exemplo) não romperiam com os principios básicos do fordismo, entre os quais a separação entre concepção e execução e o monopólio gerencial em termos do controle do processo de programação da tecnologia computadorizada, da esfera da pesquisa e desenvolvimento e do processo de informação e difusão (Larangeira, 1999).

Wood (1991) reforça essa última tese, argumentando que o controle do tempo, aspecto principal do taylorismo, seria mantido, embora não concretizado da mesma forma no toyotismo ${ }^{5}$, pois deixa de ser imposto individualmente pela máquina e passa a ser uma ação dos próprios trabalhadores. Segundo o autor, a gerência japonesa, ícone desse novo modelo, ainda permanece projetando postos de trabalho de ciclos curtos, fragmentando a mão-de-obra e operando segundo concepções de trabalho padronizado.

Hirata $(1998,1994)$ traz importante contribuição para a discussão dessa dicotomia - superação/aperfeiçoamento do modelo fordista - revelando o gênero como um importante elemento de análise e compreensão desse processo.

Hirata $(1998,1994)$ destaca que uma visão dicotômica entre formas "antigas" e "novas" de organização do trabalho não permite perceber a complexidade da realidade das mudanças produtivas, pois práticas tayloristas ainda estão presentes nas "novas" formas de organizações do trabalho ${ }^{6}$. A introdução do enfoque de gênero pode contribuir para a superação dessa dicotomia, possibilitando perceber que rupturas e continuidades são construídas de formas diferenciadas em diferentes empresas, setores ou atividades, utilizando, nesse processo, o trabalho masculino e o feminino.

De acordo com a autora, essa situação pode ser exemplificada nas diferenças detectadas numa mesma empresa quando se comparam setores feminizados que permanecem em grande parte taylorizados e setores masculinizados nos quais se percebem alterações no modelo de organização do trabalho. Enquanto atividades masculinas passariam a exigir mais responsabilidade, trabalho em grupo e competência técnica; as atividades exercidas majoritariamente por mulheres permaneceriam sendo controladas segundo modelos tayloristas de organização do trabalho e obedecendo a cadências e ritmos impostos por linhas de montagem.

Devemos considerar que o novo operário tomado como padrão - o "toyotista" - é geralmente masculino, estável no emprego, trabalhador de uma grande empresa, detentor de uma visão do conjunto do processo do trabalho e produção, no qual se faz necessário julgar, discernir, intervir, resolver problemas e propor soluções. Ele é considerado como sujeito do processo de trabalho, com capacidade de se envolver, de mobilizar recursos próprios em vistas da atividade produtiva. A implicação subjetiva e a mobilização psíquica desse trabalhador são garantidas através de um sistema de emprego em que a valorização da carreira estável coexiste com o medo de passar para uma subcontratação precária, como o que ocorre na organização industrial japonesa 
(Hirata, 1997).

Hirata (2002) também destaca que as transformações recentes dos paradigmas produtivos, e as mudanças na organização das empresas têm acarretado, desde a década de 1980, uma crise na noção de "posto de trabalho" em proveito da noção de "trabalho em equipe". Nesse contexto, a autora destaca a definição de competência constituída de três dimensões":

a) a iniciativa e a responsabilidade do indivíduo;

b) a inteligência prática nas situações que se apóia sobre os conhecimentos adquiridos e os transforma;

c) a faculdade de mobilizar redes de atores, co-responsáveis, em torno das mesmas situaçöes.

A lógica da competência coloca, em primeiro plano, o sujeito do processo de trabalho, centrando a atenção mais sobre o indivíduo e suas qualidades do que sobre o posto de trabalho. No entanto, as caracteristicas desse modelo (iniciativa, responsabilidade, resposta aos imprevistos, etc.) são pouco observáveis quando se trata de uma grande parte do trabalho feminino e do trabalho não qualificado (independente do sexo). Deve-se considerar que essa lógica pode ser potencialmente um fator de exclusão, sobretudo das mulheres, pois embora possa favorecer a entrada feminina em cargos de gerência, também pode levar à criação de uma categoria de trabalhadores não empregáveis por näo terem as "competências" desejadas pelo mercado. Ressaltamos que, nesse modelo, as capacidades relacionais não são vistas como qualificações/competências quando se trata da mão-de-obra feminina, tendendo mais a desvalorizar do que valorizar o trabalho das mulheres, inversamente ao que acontece com tais capacidades quando se trata dos homens (Hirata, 2002).

O modelo japonês, inspirador desse "novo" paradigma de produção industrial, segundo Hirata (1993), pode ser visto a partir de três acepções:

a) modelo japonês de relações industriais: sistema de emprego adotado nas grandes empresas japonesas para seus assalariados do sexo masculino contratados regularmente. Portanto, um modelo excludente, na medida que esse sistema, constituído pelo emprego vitalício, promoção por tempo de serviço, sindicato de empresa e pela baixa taxa de desemprego, não é válido para mulheres, empregados temporários, de empreiteiras e trabalhadores das pequenas e médias empresas;

b) modelo japonês de organização industrial interempresas: modelo dualista e hierarquizante, em que se estabelecem trocas de tipo muito particulares entre fornecedores e subcontratados, de em lado, e as grandes empresas, de outro;

c) modelo japonês de organização do trabalho e da empresa: modalidade de divisão social de trabalho na empresa, na qual não há alocação do trabalhador a um posto de trabalho específico, o que significa um funcionamento baseado na polivalência e rotação das tarefas (de fabricação, manutenção, controle de qualidade, gestão de produção); predominio do grupo de trabalho sobre os indivíduos; divisão de trabalho menos nítida entre operários da manutenção e da fabricação, entre as diferentes categorias hierárquicas (contramestres, engenheiros, chefes de fábrica, trabalhadores); demarcação mais difusa entre direção e execução com o trabalhador, conhecendo e dominando melhor o processo global da produção. 
Pode ainda ser vista como um conjunto de métodos e técnicas de organização do trabalho e da produção (Just in Time, Kanban, Círculos de Controle de Qualidade, etc.).

No Brasil, o modelo japonês tem sido usado para delimitar noções com extrema diversidade e abrangência, mas, segundo Salerno (1993), tem como noção central a flexibilidade, percebida a partir das seguintes formas:

a) flexibilidade da organização da produção, referindo-se à aptidão de ajustar equipamentos a demandas variáveis;

b) capacidade dos trabalhadores para trocar de posto de trabalho numa dada organização associada à idéia de polivalência e da ampla formação desses trabalhadores;

c) flexibilidade nos contratos de trabalho que indica a possibilidade de variar o emprego, a jornada de trabalho e o local de realização do trabalho;

d) flexibilidade dos salários, referindo-se à possibilidade de revisão permanente dos salários em função da conjuntura;

e) redução dos encargos e regulamentação social expressa pela redução da carga fiscal, encargos, regulamentações públicas que limitem a liberdade de gestão das empresas.

Para Hirata (2002), a flexibilidade pode se concretizar nos modelos de produção, adotados em âmbito internacional, por meio do trabalho feminino, bem como nas variações no volume de emprego e no tempo de trabalho.

A precarização surge como uma das conseqüências desse "novo" modelo produtivo que ocorre, de acordo com Hirata (1998), num duplo processo: se por um lado exige-se estabilização com maior envolvimento do sujeito no processo de trabalho, por outro, percebe-se um processo de precarização dos laços empregatícios (desemprego prolongado, emprego precário, flexibilidade do uso de mão-de-obra). Enquanto o processo de precarização tem ocorrido em âmbito mundial, a maior estabilização tem privilegiado, sobretudo, trabalhadores masculinos de grandes empresas dos paises do Norte. Esse processo tem ocorrido inicialmente com o trabalho feminino e aponta para a dispersão das situações de trabalho. Posthuma (1998) considera-o como uma espécie de "inserção excluida" que comumente envolve o trabalho feminino. A conseqüência, segundo ela, seria, a priori, a posição desvantajosa das mulheres no mercado de trabalho cuja participação estaria imbricada com a segmentação desse mercado.

Sobre o trabalho feminino nesse "novo" contexto, pesquisas de Abramo (1994, 1997, 1998) constatam que a modernização empresarial, a reestruturação produtiva $e$ a inovação tecnológica não reduzem, de forma significativa, a segregação vertical e horizontal de gênero no mundo do trabalho.

A diversificação das condições de trabalho, particularmente referente ao trabalho masculino e feminino, permite dizer que o atual mundo do trabalho é composto por mundos do trabalho cujas realidades podem ser desvendadas a partir do conhecimento da realidade concreta dos trabalhadores e trabalhadoras, o que exige adentrar nas fábricas/empresas/ setores, verificando como as mudanças têm ocorrido nesses ambientes. Com esse objetivo, analisamos os resultados de algumas pesquisas sobre gênero e trabalho desenvolvidas no Brasil (vinte e quatro trabalhos de dezessete autoras), tratadas na seqüência. 


\begin{tabular}{|l|l|l|l|l|}
\hline Autor & Universo & Objetivo(s) & Metodologia & Pricipais Resultados \\
\hline $\begin{array}{l}\text { 1.Abramo } \\
\text { (1994. }\end{array}$ & $\begin{array}{l}\text { Setor industrial } \\
\text { e de serviços; }\end{array}$ & $\begin{array}{l}\text { 1) Estudar a realidade } \\
\text { do trabalho a partir das }\end{array}$ & $\begin{array}{l}\text { 1) Dados oriundos } \\
\text { de diferentes }\end{array}$ & $\begin{array}{l}\text { 1) ampliaçăo da participação feminina no mercado de trabalho na América } \\
\text { Latina; }\end{array}$
\end{tabular}

(1994.

1997 América Latina $\quad \begin{aligned} & \text { do trabalho a partir } \\ & \text { cadeias produtivas; }\end{aligned}$

1998

2) Analisar os processos

de reconversão $\theta$

inoyação tecnológica

e as conseqüências

sobre o emprego e a

qualificaçäo feminina;

formas de organizaçăo

do trabalho menos gênero.

\begin{tabular}{|c|c|}
\hline $\begin{array}{l}\text { 2. Araújo } \\
\text { e Amorim } \\
(2001 / 02)\end{array}$ & $\begin{array}{l}\text { Indústria de } \\
\text { confecção } \\
\text { da regiäo de }\end{array}$ \\
\hline
\end{tabular}

(2001/02)

Discutir as redes de

subcontrataçăo e novos

usos do trabalho

em domicilio como

elementos centrais

da reestruturação do

anos 90.

\begin{tabular}{|l|l|} 
& \\
\hline $\begin{array}{l}\text { 3. Araúioe e } \\
\text { Oliveira (sd) }\end{array}$ & $\begin{array}{l}\text { Setor de } \\
\text { autopeças e } \\
\text { elotroetotôn }\end{array}$ \\
\hline
\end{tabular}

Oliveira (sd)

autopeças e

eletroeletrónicos:

Estado

\begin{tabular}{|l|l|}
\hline & Paulo \\
\hline $\begin{array}{l}\text { 4. Borges e } \\
\text { (2000) }\end{array}$ & $\begin{array}{l}\text { Mercado } \\
\text { de trabalho } \\
\text { da Regiāo } \\
\text { metropolitana de } \\
\text { Salvador (RMS), } \\
\text { Bahia. }\end{array}$ \\
\hline
\end{tabular}

1) Compreender 0

impacto dos processos

de reestruturaçăo

produtiva sobre a

divisáo sexual do

trabalho, a natureza, as

condiçoes de trabalho e

a vida reprodutiva das

trabalnadoras;

2) Conhecer a

trabalhadoras sobre

esse processo.

Analisar os principais

traços da participaçáa

Teminina na mundo do

de diferentes

Latina

pesquisadores;

2) a inovaçâo tecnológica e a modernizaçāo empresarial não reduziram de

2) Pesquisa em

mecânica o de

limentaç⿰

Argentina, Bolivia,

Brasil, Chile

Colômbia México

(1992-1993).

forma significativa a segregação vertical e horizontal do trabalho feminino feminina;

3) os efeitos dos processos de reestruturação produtiva e inovação

tecnológica sobre o trabalho feminino no setor industrial diferenciam-se dos efeitos no setor de servicos:

4) existéncia nas cadeias produtivas de uma progressiva precarizaçåo das condicōes de trabalho e emprego fortemente marcada pela variável gênero num deslocamento das "empresas-cabeça" para as "empresas-mão",

作

6) as mulheres ocupam lugar secundário nas politicas de recursos humanos.

Pesquisa realizada

1) as mulheres constituem a força de trabatho subcontratada e ocupam as no periodo 1998

a 2000 , na regiắo

de Campinasisp

em empresas

de confecção de

pequeno e meio

porte, bem como subcontratação.

Pesquisa realizada

em 5 empresas,

sendo três grandes

empresas de auto-

peças, uma de médi

porte de aparelhos

e um

e um pequeno

fabricante de

eletroeletrônicos.

1) as mudanças decorrentes da reestruturação das empresas năo alteraram, de forma significativa, a divisão sexual do trabalho, pois as trabalhadoras permaneceram, na sua grande maioria, excluidas dos setores postoslorizados,

2) trabalhadoras percebem que as mudanças introduzidas nas empresas

posiççes inferiores e mais vulneráveis na cadeia produtiva;

) a presença feminina contribul para assegurar (por meio de baixos salários, 政 produtividade e da lucratividade em toda a rede de subcontratação. de um lado, melhoraram suas condiçōes de trabalho, mas de outro, intensificaram o ritmo de trabalin

3) presença de sintomas de deterioração de aspectos da vida sexual e reprodutiva das trabalhadoras e principalmente do acometimento das doenças ocupacionais (LER) e manifestaçőes de sofrimento mental.

Dados quantitativos

1) Ampliação da participação feminina no mercado de trabalho da RMS;

das PNADs

de 1992 a 1997.

) Ampliça da participaça femina no mercado de trabalho da RMS;

ocupaçōes de baixa qualidade

de posiçăo feminina desvantajosa no mercado de trabalho

de 1990, tomando-se

como exemplo o caso

da RMS. 


\begin{tabular}{|c|c|c|c|c|}
\hline Autor & Universo & Objetivo(s) & Metodologia & Pricipais Resultados \\
\hline $\begin{array}{l}\text { 5. Brito } \\
(1999)\end{array}$ & $\begin{array}{l}\text { Indústrias } \\
\text { químicas, Estado } \\
\text { do Estado do Rio } \\
\text { de Janeiro. }\end{array}$ & $\begin{array}{l}\text { 1) Revelar mecanismos } \\
\text { de ocultaçăo dos } \\
\text { riscos do trabalho das } \\
\text { mulheres; } \\
\text { 2) Mostrar as relaçōes } \\
\text { entre a organizaçäo } \\
\text { do trabalho e a saúde } \\
\text { das trabalhadoras nas } \\
\text { indústrias de processos } \\
\text { quimicos. }\end{array}$ & $\begin{array}{l}\text { Dados qualitativos } \\
\text { a) entrevistas com } \\
\text { trabalhadores(as); } \\
\text { ex-trabalhadores (as) } \\
\text { e representantes } \\
\text { sindicais (1995); } \\
\text { b) observaçöes do } \\
\text { processo de trabalho } \\
\text { (1995). }\end{array}$ & $\begin{array}{l}\text { 1) Forte participaçăo feminina na indústria quimica do RJ; } \\
\text { 2) descompasso entre nivel de instrução feminina e respectivo cargo, } \\
\text { 3) concentração feminina em empresas menores terceirizadas, em funçőes "taylorizadas", com } \\
\text { baixa remuneraçăo e com exigência das "qualidades femininas"; } \\
\text { 4) ritmo de trabalho doméstico feminino intensificado com a atividade profissional: } \\
\text { 5) construçăo da invisibilidade da problemática dă saúde da mulher. }\end{array}$ \\
\hline $\begin{array}{l}\text { 6. Bruschini } \\
\text { e Lombardi } \\
\text { (1999) }\end{array}$ & $\begin{array}{l}\text { Ocupaçóes de } \\
\text { nivel superior de } \\
\text { prestigio. Brasil. }\end{array}$ & $\begin{array}{l}\text { Investigar caracteristicas } \\
\text { e dinâmica da inserçăo } \\
\text { feminina nas ocupaçóes } \\
\text { de nivel superior de } \\
\text { prestigio-Medicina, } \\
\text { Engenharia, Arquitetura } \\
\text { e Direito. }\end{array}$ & $\begin{array}{l}\text { Dados quantitativos } \\
\text { - RAIS de } 1990 \text {. } \\
1993 \text { e } 1996 \text {. }\end{array}$ & $\begin{array}{l}\text { 1) Consolidação da presença feminina na Medicina, Engenharia, Arquitetura e Direito; } \\
\text { 2) profissionais femininas mais jovens que os profissionais masculinos, } \\
\text { 3) tempo de permanência das mulheres no emprego é ligeiramente inferior ao tempo masculino; } \\
\text { 4) mulheres recebem salários inferiores aos salários masculinos; }\end{array}$ \\
\hline $\begin{array}{l}\text { 7. Bruschini } \\
\text { e Lombardi } \\
(2000)\end{array}$ & $\begin{array}{l}\text { Setor de serviços } \\
\text { e profissionais de } \\
\text { nivel universitário, } \\
\text { Brasil. }\end{array}$ & $\begin{array}{l}\text { Analisar a participação } \\
\text { das mulheres no } \\
\text { mercado de trabalno } \\
\text { em dois pólos } \\
\text { opostos de atividades } \\
\text { - emprego doméstico } \\
\text { (ocupação de má } \\
\text { qualidade) e carreiras } \\
\text { universitárias ("boas" } \\
\text { ocupaçōes) quais } \\
\text { sejam a Engenharia, a } \\
\text { Arquitetura, a Medicina } \\
\text { e o Direito. }\end{array}$ & $\begin{array}{l}\text { Dados quantitativos: } \\
\text { Censo Demográfico, } \\
\text { PNADs dos anos de } \\
\text { 1990 a } 1997 \text { e RAIS } \\
\text { até } 1996 .\end{array}$ & $\begin{array}{l}\text { 1) sobre emprego doméstico: a) maior gueto feminino- }-90 \% \text { são mulheres; b) precariedade }{ }^{10} \\
\text { do emprego doméstico; contudo, há sinais de mudanças com ampliação do número de } \\
\text { registros em carteira e melhoria salarial; } c \text { ) envelhecimento da categoria; } \\
\text { 2) sobre profissionais de nivel universitario, a) perfil feminino diferenciado do masculino pelo } \\
\text { fato das mulheres serem mais jovens que os homens; b) distribuição por gënero nos setores } \\
\text { publicos e privados e carga horária de trabalho assemelhada para homens e mulheres; c) } \\
\text { desigualdades salariais - mulheres recebem menos; } \\
\text { 3) diferenças salariais exorbitantes entre mulheres situadas em pólos diferenciados; } \\
\text { 4) trabalho doméstico e apoio necessário para que as profissionais de nivel superior possam se } \\
\text { dedicar á própria carreira. }\end{array}$ \\
\hline $\begin{array}{l}\text { 8.Bruschini } \\
(1994,2000)\end{array}$ & $\begin{array}{l}\text { Mercado de } \\
\text { trabalho brasileiro }\end{array}$ & $\begin{array}{l}\text { Perceber mudanças } \\
\text { e persistências na } \\
\text { dinâmica e no perfil } \\
\text { do mercado de } \\
\text { trabalho (décadas de } \\
1980 \text { e 1990) através } \\
\text { da comparação da } \\
\text { participação masculina e } \\
\text { feminina. }\end{array}$ & $\begin{array}{l}\text { Dados Quantitativos: } \\
\text { PNADs e IBGE para } \\
\text { os anos de } 1985 \\
1990,1993 \text { e } 1995 \\
\text { Censo demograficol } \\
\text { Mão-de-obra de } 1980 \\
\text { e } 1991\end{array}$ & 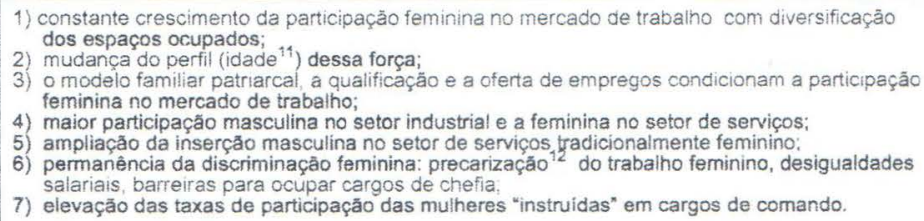 \\
\hline
\end{tabular}




\begin{tabular}{|c|c|c|c|c|}
\hline Autor & Universo & Objetivo(s) & Metodologia & Pricipais Resultados \\
\hline $\begin{array}{l}\text { 9. Hirata } \\
\text { (2002) }\end{array}$ & $\begin{array}{l}\text { Setor industrial } \\
\text { e de serviços, } \\
\text { paises do norte e } \\
\text { sul, Brasil. }\end{array}$ & $\begin{array}{l}\text { Discutir as mudanças } \\
\text { na divisão do trabalho e } \\
\text { nas relaçôes de gênero. }\end{array}$ & $\begin{array}{l}\text { Dados oriundos de } \\
\text { pesquisas de outras } \\
\text { autoras e pesquisas } \\
\text { empiricas em } \\
\text { indüstrias brasileiras } \\
\text { em 1999; }\end{array}$ & $\begin{array}{l}\text { 1) bipolarização da inserção profissional feminina; } \\
\text { 2) o modelo de competência e pouco observável no trabalho feminino }{ }^{14} \text {. } \\
\text { 3) novos contornos da divisão sexual do trabalho permitem a persistência da própria divisão } \\
\text { sexual do trabalho cujo paradigma é assentado sobre a hierakquia social da superioridade } \\
\text { masculina; } \\
\text { 4) novo paradigma da divisão sexual do trabalho requer nova divisão sexual do trabalho } \\
\text { profissional e doméstico. }\end{array}$ \\
\hline $\begin{array}{l}\text { 10.Lavinas } \\
(2000)\end{array}$ & $\begin{array}{l}\text { Seis regiōes } \\
\text { metropolitanas, } \\
\text { Brasil. }\end{array}$ & $\begin{array}{l}\text { Examinar as } \\
\text { caracteristicas do } \\
\text { desemprego feminino } \\
\text { em comparaçăo com o } \\
\text { masculino nas principais } \\
\text { areas metropolitanas } \\
\text { do pais. }\end{array}$ & $\begin{array}{l}\text { Dados quantitativos } \\
\text { das PNADs de } 1985 \\
\text { a } 1995 \text { e } \text { PME }^{15}\end{array}$ & $\begin{array}{l}\text { 1) taxa de desemprego feminino em elevação; } \\
\text { 2) ampliaçăo do desemprego feminino em decorrência de uma crescente disputa masculina no } \\
\text { setor de Serviços; } \\
\text { 3) taxas de desemprego feminino mais elevadas no Comércio e na Indústria; } \\
\text { 4) desemprego afeta mais as mulheres com nivel de instruçăo intermediário } \\
\text { 5) menores taxas de desemprego entre as mulheres com nivel superior. }\end{array}$ \\
\hline $\begin{array}{l}\text { 11.Melo } \\
\text { (2001) }\end{array}$ & $\begin{array}{l}\text { Setor industrial, } \\
\text { Brasil. }\end{array}$ & $\begin{array}{l}\text { Analisar a evolução do } \\
\text { emprego industrial a } \\
\text { partir da perspectiva do } \\
\text { feminino. }\end{array}$ & $\begin{array}{l}\text { Dados quantitativos } \\
\text { - Pnad/ IBGE. } \\
\text { Periodo analisado } \\
1985 \text { a } 1995 .\end{array}$ & $\begin{array}{l}\text { 1) manutenção da taxa de participação feminina no período analisado, inclusive com um pequeno } \\
\text { aumento - de } 26,35 \% \text { (em } 1985 \text { ) passou para } 28,13 \% \text { em } 1997 \text {; } \\
\text { 2) a maior concentraçăo feminina ocorre na indústria têxtil e de calçados - } 50 \% \text { da força de trabalho } \\
\text { é composta por mulheres; } \\
\text { 3) menor taxa de participaçẫo feminina é na metalurgia - } 10,38 \% \text { da força de trabalho é feminina. }\end{array}$ \\
\hline $\begin{array}{l}\text { 12.Posthuma } \\
\text { (1998) }\end{array}$ & $\begin{array}{l}\text { Indústria } \\
\text { automobilistica, } \\
\text { Estado de Säo } \\
\text { Paulo. }\end{array}$ & $\begin{array}{l}\text { 1) Analisar a presença } \\
\text { feminina no mercado } \\
\text { de trabalho através do } \\
\text { conceito de exclusão } \\
\text { social; } \\
\text { 2) Mostrar como a } \\
\text { segregação ocupacional } \\
\text { e a definição de trabaiho } \\
\text { masculino e feminino } \\
\text { agem na "inserção } \\
\text { excluida". }\end{array}$ & $\begin{array}{l}\text { 1) Dados } \\
\text { quantitativos: PNADs; } \\
\text { 2) Dados Qualitativos: } \\
\text { entrevistas com } \\
\text { gerentes, homens e } \\
\text { muiheres do chão de } \\
\text { fábrica. } \\
\text { 3) Universo de } \\
\text { pesquisa: } 2 \\
\text { empresas. }\end{array}$ & $\begin{array}{l}\text { 1) nivel de escolaridade feminino superior ao minimo exigido para admissăo ao emprego; } \\
\text { 2) tarefas femininas aplicam as habilidades "naturais" das mulheres; } \\
\text { 3) trabalho feminino organizado de forma segregada de outras atividades da empresa, repetitivo } \\
\text { e destituido de conteudo; } \\
\text { 4) segregaçăo sexyal nos cursos de treinamento - participaçăo feminina restrita a cursos } \\
\text { comportamentais } \\
\text { 5) processo de exclusão feminina dentro do mercado de trabalho (inserção excluida). }\end{array}$ \\
\hline $\begin{array}{l}\text { 13.Rizek e } \\
\text { Leite (1997, } \\
\text { 1998) }\end{array}$ & $\begin{array}{l}\text { Complexo } \\
\text { químico, cadeia } \\
\text { automotiva e } \\
\text { setor metal- } \\
\text { mecânico, Brasil.. }\end{array}$ & $\begin{array}{l}\text { Apresentar pesquisas } \\
\text { recentes sobre } \\
\text { o trabalho fabril } \\
\text { interrogando elementos } \\
\text { comuns, transversais } \\
\text { a setores produtivos } \\
\text { diversos - trabalho das } \\
\text { mulheres. }\end{array}$ & $\begin{array}{l}\text { Dados de } \\
\text { investigaçర̄es em } \\
\text { quatro empresas dos } \\
\text { seguintes ramos: } \\
\text { metal-mecánica, } \\
\text { autopeças, higiene } \\
\text { bucal e cosméticos. }\end{array}$ & $\begin{array}{l}\text { 1) associaçăo de trabalho feminino a postos taylorizados cujos conteúdos săo repetitivos e } \\
\text { manuais; } \\
\text { 2) representaçóes femininas idênticas em situações heterogêneas; } \\
\text { 3) reprodução de um lugar feminino dentro e fora da fábrica e da separação do masculino e do } \\
\text { feminino. }\end{array}$ \\
\hline
\end{tabular}




\begin{tabular}{|c|c|c|c|c|}
\hline Autor & Universo & Objetivo(s) & Metodologia & Pricipais Resultados \\
\hline $\begin{array}{l}\text { 14.Segnini } \\
(1994,1998 \mathrm{a}, \\
1998 \mathrm{~b}, 2000)\end{array}$ & $\begin{array}{l}\text { Setor bancário; } \\
\text { Brasil. }\end{array}$ & $\begin{array}{l}\text { Analisar as relaçôes } \\
\text { de gênero no trabalho } \\
\text { bancário no contexto } \\
\text { caracterizado pela } \\
\text { difusão da automação. }\end{array}$ & $\begin{array}{l}\text { Dados quantitativos } \\
\text { - Recursos humanos } \\
\text { (banco estatal); } \\
\text { estudo de caso } \\
\text { de banco estatal; } \\
\text { entrevistas com } \\
\text { mulheres bancárias } \\
\text { (1993). Periodo } \\
\text { anailisado } 1986 \text { a } \\
\text { 1997. }\end{array}$ & $\begin{array}{l}\text { 1) o emprego bancário representa uma conquista social das muiheres na busca de oportunidades } \\
\text { iguais no mundo do trabalho; } \\
\text { 2) feminizaçăo progressiva da categoria dos bancários; } \\
\text { 3) trabalho ferninino maximiza a produtividade (geradora de excedentes ou desenvolvimento de } \\
\text { tarefas politicas); } \\
\text { 4) mulheres são mais escolarizadas e ocupam cargos inferiores, embora existam indícios de sua } \\
\text { ascendência hierárquică: } \\
\text { 5) } 3 / 4 \text { dos casos de LER referem-se a mulheres; } \\
\text { 6) reafirmaçăo dos estereotipos masculinos e femininos na construção das qualificações } \\
\text { desejadas. }\end{array}$ \\
\hline $\begin{array}{l}\text { 15. Segnini } \\
(2001)\end{array}$ & $\begin{array}{l}\text { Setor bancário: } \\
\text { Estado de São } \\
\text { Paulo. }\end{array}$ & $\begin{array}{l}\text { Analisar as trajetórias } \\
\text { e práticas sociais } \\
\text { vivenciadas em situação } \\
\text { de desemprego ou de } \\
\text { retorno ao mercado } \\
\text { de trabalho mediante } \\
\text { formas precárias de } \\
\text { reinserção, resgatando } \\
\text { as especificidades de } \\
\text { gênero. }\end{array}$ & $\begin{array}{l}\text { 1) Entrevistas com } \\
\text { homens e mulheres } \\
\text { que aderiram ao } \\
\text { Plano de Demissão } \\
\text { Voluntária (PDV) } \\
\text { - pesquisa realizada } \\
\text { em } 1998 \text {. }\end{array}$ & $\begin{array}{l}\text { 1) grande esforço por parte dos trabalhadores que aderiram ao PDV de reinserção no mercado } \\
\text { de trabalho: } \\
\text { 2) o adoecimento feminino (LER e estresse) é maior que o masculino tanto em situações de } \\
\text { trabalho quanto de desemprego; } \\
\text { 3) o desemprego atinge moralmente mais os homens; } \\
\text { 4) menor adesăo ao PDV entre as mulheres interpretado de forma pejorativa e desqualificadora } \\
\text { - sinônimo de acomodaçăo. }\end{array}$ \\
\hline $\begin{array}{l}\text { 16.Silva } \\
\text { (1995) }\end{array}$ & $\begin{array}{l}\text { Indủstrias têxtil, } \\
\text { alimentaçăo, } \\
\text { vestuário e fumo; } \\
\text { Rio Grande do } \\
\text { Sul. }\end{array}$ & $\begin{array}{l}\text { Examinar procedimentos } \\
\text { de recrutamento de } \\
\text { mão-de-obra em sete } \\
\text { empresas industriais } \\
\text { de Porto Alegre (de } \\
\text { ramos que empregam } \\
\text { preferencialmente } \\
\text { mulheres). }\end{array}$ & $\begin{array}{l}\text { Pesquisa realizada } \\
\text { em sete empresas: } \\
\text { uma do ramo do } \\
\text { fumo e outra da } \\
\text { alimentação, três } \\
\text { do vestuário e } \\
\text { duas do ramo têxtil. } \\
\text { Dados quantitativos } \\
\text { fomecidos } \\
\text { pelas empresas } \\
\text { pesquisadas; dados } \\
\text { qualitativos obtidos } \\
\text { por entrevistas. }\end{array}$ & $\begin{array}{l}\text { 1) recrutamento de trabaihadores para as fábricas ocorre de acordo com as concepç̄es vigentes } \\
\text { do masculino e do feminino (suas habilidades e caracteristicas "naturais" gerando trabalho de } \\
\text { homem e trabalho de mulher); } \\
\text { 2) as mulheres estăo em postos de trabalho, técnica e funcionaimente subordinados, para executar } \\
\text { tarefas "leves", simples e repetitivas que demandam habilidades "femininas" } \\
\text { 3) raros os programas de capacitaçăo para mulheres e promoção feminina para cargos de chefia. }\end{array}$ \\
\hline $\begin{array}{l}\text { 17. Stein } \\
(2000)\end{array}$ & $\begin{array}{l}\text { Setor } \\
\text { Eletroeletrônico, } \\
\text { Paraná. }\end{array}$ & $\begin{array}{l}\text { Analisar especificidades } \\
\text { do gênero feminino } \\
\text { na indústria } \\
\text { eletroeletrónica. }\end{array}$ & $\begin{array}{l}\text { Pesquisa em tre̊s } \\
\text { empresas do setor } \\
\text { eletroeletrónico do } \\
\text { Paraná em } 1999 . \\
\text { Dados qualitativos } \\
\text { por entrevistas com } \\
\text { homens e mulheres } \\
\text { da área de produçăo } \\
\text { e que ocupam cargos } \\
\text { de chefia. }\end{array}$ & $\begin{array}{l}\text { 1) relevância do trabalho feminino para o setor; } \\
\text { 2) exigéncia de habilidades consideradas femininas }{ }^{20} \text { para o desempenho de grande parte das } \\
\text { funçoes de produçăo; } \\
\text { 3) desqualificaçăo do trabalho feminino; } \\
\text { 4) pouca participaçăo feminina em cargos de chefia e restritas oportunidades de carreira e } \\
\text { qualificacáao; } \\
\text { 5) tarefas femininas são manuais, monótonas e repetitivas; } \\
\text { 6) alta incidência de LER entre as mulheres. }\end{array}$ \\
\hline
\end{tabular}


A primeira tendência que se destaca no conjunto das pesquisas analisadas é a ampliação da participação feminina no mercado de trabalho brasileiro. Utilizando os dados apresentados por Bruschini (2000) e acrescentando os referentes a 2003, verificamos (tabela 1.1) que, entre 1985 a 2003, a participação feminina na população economicamente ativa (PEA ${ }^{21}$ ) passou de $33,5 \%$ para $42,7 \%$, demonstrando o crescimento constante do número de mulheres que trabalham ou estão procurando emprego. Segundo a autora,

[...] o "significativo aumento das atividades das mulheres - uma das mais importantes transformações ocorridas no País desde os anos 70 - seria resultado não apenas da necessidade econômica e das oportunidades oferecidas pelo mercado, em conjunturas especificas, mas também, em grande parte, das transformações demográficas, culturais e sociais que vêm ocorrendo no Brasil e que têm afetado as mulheres e as familias brasileiras. A intensa queda da fecundidade reduziu o número de filhos por mulher, sobretudo nas cidades e regiões mais desenvolvidas do País, liberando-a para o trabalho. A expansão da escolaridade e o acesso às universidades viabilizaram o acesso das mulheres a novas oportunidades de trabalho. [...] transformaçōes nos padrões culturais e nos valores relativos ao papel social da mulher, intensificadas pelo impacto dos movimentos feministas desde os anos 70 e pela presença cada vez mais atuante das mulheres nos espaços públicos, alteraram a constituição da identidade feminina, cada vez mais voltada para o trabalho produtivo. A consolidação de tantas mudanças é um dos fatores que explicaria não apenas o crescimento da atividade feminina, mas também as transformações no perfil da força de trabalho desse sexo. (BRUSCHINI, 2000, p. 16)

Consoni (1998) observa que a expansão do trabalho feminino no mercado de trabalho refletiu sobre a incorporação da mulher no setor industrial brasileiro que se intensificou, a partir da década de 1970. A inserção da mulher na indústria passa a ocorrer não só nos setores tradicionalmente femininos como têxtil, vestuário e calçados, mas também nos setores metal-mecânico, plástico, material elétrico e eletrônico, farmacêutico e químico.

Tabela 1: Distribuição da população economicamente ativa no Brasil, por sexo (1985 a 2003)

\begin{tabular}{|c|c|c|c|c|c|c|c|c|c|}
\hline \multirow{2}{*}{} & \multirow{2}{*}{ Sexo } & \multicolumn{2}{|c|}{1985} & \multicolumn{2}{c|}{1990} & \multicolumn{2}{c|}{1995} & \multicolumn{2}{c|}{$2035^{22}$} \\
\cline { 2 - 9 } & & $\mathbf{N}$ & $\%$ & $\mathbf{N}$ & $\%$ & $\mathbf{N}$ & $\%$ & $\mathbf{N}$ & $\%$ \\
\hline \multirow{2}{*}{$\begin{array}{c}\text { PEA } \\
\begin{array}{c}\text { N em } \\
\text { milhōes de } \\
\text { pessoas }\end{array}\end{array}$} & Masculino & 36,6 & 66,5 & 41,6 & 64,5 & 44,2 & 59,6 & 50,3 & 57,3 \\
\cline { 2 - 10 } & Feminino & 18,4 & 33,5 & 22,9 & 35,5 & 30,0 & 40,4 & 37,5 & 42,7 \\
\cline { 2 - 9 } & Total & 55,0 & 100 & 64,5 & 100 & 74,2 & 100 & 87,8 & 100 \\
\hline
\end{tabular}

Fontes: Bruschini (2000:65) a partir de dados do FIBGE ${ }^{23}$ e PNADs (1985, 1990 e 1995); IBGE, PNADs 2003. Nota: $N=$ números absolutos.

Em segundo lugar, os estudos analisados demonstram que a ampliação da participação da mulher no mercado de trabalho tem coexistido com a permanência do processo de segregação, discriminação e precarização do trabalho feminino, bem como das desigualdades salariais entre homens e mulheres. 
Em relação ao trabalho industrial, observamos, particularmente nos trabalhos de Araújo e Oliveira (sd), Brito (1999), Posthuma (1998), Risek e Leite (1997, 1998), Segnini (1994, 19981, 1998b, 2000, 2001), Silva (1995) e Stein (2000), que a força de trabalho feminina permanece, em grande parte, excluida dos setores modernizados tecnologicamente e concentrada em postos taylorizados marcados por tarefas repetitivas, manuais e monótonas. Como conseqüência desse processo, verificamos um elevado número de casos de doenças ocupacionais, sobretudo lesões por esforços repetitivos, entre as mulheres.

Os estudos de Abramo $(1994,1997,1998)$ e Araújo e Amorim (2001/2002) apontam que as mulheres ocupam posições inferiores e vulneráveis nas cadeias produtivas. A presença feminina ocorre, em grande medida, nas empresas subcontratadas, ocorrendo uma progressiva precarização das condições de trabalho feminino.

Segnini (1998) observa que o crescimento da participação da mulher no mercado de trabalho se insere num contexto de reestruturação, caracterizado pelo aumento do trabalho assalariado sem registro, dos contratos temporários e empregos terceirizados. Aspecto também abordado por Bruschini (2000, p. 31) que destaca: "o trabalho feminino não deixa de ser caracterizado como mais precário em relação ao masculino. Ao contrário, há evidências de que a desigualdade de gênero continua a demarcar o mercado brasileiro."

A partir de dados da FIBGE e PNADs (1995) sobre remuneração e local onde os trabalhadores desempenham suas atividades, Bruschini (2000) exemplifica essa precariedade:

a) mais da metade das ocupadas (como ocorre com os homens) trabalhava em lojas, oficinas ou escritórios, mas 12,4\% desse trabalho feminino era realizado no próprio domicilio e $17,5 \%$ no domicílio do patrão ( $92 \%$ dessas últimas eram empregadas domésticas);

b) $90 \%$ das empregadas domésticas ganhavam menos que 2 salários minimos e $82 \%$ não tinham registro em carteira;

c) $13,1 \%$ das trabalhadoras e $8,0 \%$ dos trabalhadores homens desempenhavam atividades não remuneradas. Entre essas mulheres, $70 \%$ tinham menos de 19 anos e $16 \%$ mais de 60 anos e estavam concentradas no setor agricola (41\%) e comércio (14\%);

d) mais da metade das trabalhadoras realizava atividades precárias que se situavam no segmento informal da economia, ou seja, situavamse nos nichos mais desfavorecidos de atividade econômica: emprego doméstico ( $17 \%$ das ocupadas e $0,8 \%$ dos ocupados), as não remuneradas, consumo próprio ou familiar $(9,3 \%$ das ocupadas e $1,9 \%$ dos homens ocupados) e trabalho domiciliar.

A compreensão, desse processo de precarização requer, segundo Hirata (1998), uma perspectiva de análise que inclua dimensões explicativas extraprofissionais, como a responsabilidade feminina pelas tarefas domésticas e a relação de poder entre os sexos na sociedade. A necessidade de conciliar trabalho doméstico e trabalho profissional pode ser um dos fatores que levam as mulheres a aceitar um emprego de tempo parcial24 ou formas precarizadas de emprego. 
Segnini (1998) lembra que, mesmo sendo a precarização do trabalho um processo social que atinge todos os trabalhadores, as maiores taxas de informalidade e precariedade de trabalho são vivenciadas pelas mulheres, representando uma espécie de "balão de ensaio" que testa a viabilidade desse modelo para toda a classe trabalhadora: "as mulheres foram pioneiras ao ocupar postos de trabalhos precários que estavam por vir, para ambos os sexos, no contexto da reestruturação produtiva." (SEGNINI, 1998, p. 38).

Formas precarizadas de trabalho representam formas de "inserção excluída" no mercado de trabalho, modelo no qual a exclusão feminina ocorre mesmo quando a mulher se encontra empregada. A exclusão feminina dentro e fora do mercado de trabalho, segundo Posthuma (1998), aparece expressa em termos de segregação horizontal - ocupacional e setorial - e segregação vertical - trabalho desprotegido ou precário (incluindo o trabalho em tempo parcial e informal), remuneração menor por hora trabalhada e mobilidade de carreira restrita. A terceirização do trabalho no setor industrial exemplifica a concretizaçäo da "inserção excluída", pois, embora crie um número significativo de oportunidades de emprego para as mulheres, muitas dessas atividades profissionais são desprotegidas ou precárias.

No que se refere à permanência da desigualdade de gênero nos rendimentos, a constatação de que as mulheres recebem salários inferiores aos masculinos tem se apresentado praticamente como uma constante nas diversas pesquisas realizadas. Segnini (1998) mostra que o aumento do espaço ocupado pelas mulheres no mercado de trabalho não tem refletido em igualdade salarial com os homens, pois qualquer que seja a ocupação, os salários femininos são inferiores aos masculinos.

Bruschini (2000) destaca que a desigualdade salarial25 entre homens e mulheres tem caracterizado o mercado de trabalho de forma geral e a discriminação feminina não se restringe a determinados setores econômicos, número de horas trabalhadas, posição/vínculo com o trabalho, ocupação desempenhada ou nivel de escolaridade, ilustrando essa afirmação com dados da PNADs:

a) em 1990, 55\% das mulheres empregadas tinham carteira assinada, enquanto entre os homens esse percentual era superior a $61 \%$;

b) em 1992, funcionários públicos de nivel superior recebiam, se homens, em média, 9,1 salários mínimos e, se mulher, 6,1 salários mínimos;

c) Em $1995,47,9 \%$ das mulheres (o percentual masculino é $40 \%$ ) recebiam até 2 salários minimos mensais; as mulheres recebiam aproximadamente $64 \%$ dos salários masculinos; $46 \%$ das mulheres e $39 \%$ dos homens que trabalhavam no setor formal de economia com periodo regular ( $40 / 44$ horas semanais) recebiam até 2 salários mínimos mensais, assim como aproximadamente $50 \%$ das mulheres e $40 \%$ dos homens que trabalham de 15 a 39 horas semanais também estão incluídos nessa faixa salarial. O número de mulheres que trabalhava até 14 horas semanais - atividades que tendem a não ter remuneração - é mais do que o triplo do número de homens nessas mesmas condições; $50 \%$ dos homens com 11 a 14 anos 
de estudos recebiam mais de 5 salários minimos, enquanto apenas $23,5 \%$ das mulheres com essa escolaridade estavam nessa faixa salarial; 2/3 dos homens com mais de 15 anos de estudo ganhavam mais de 10 salários mínimos e apenas 1/3 das mulheres com mesma escolaridade tinham rendimentos equivalentes; $72 \%$ das mulheres e $69 \%$ dos homens que integravam o serviço público (trabalhadores com estabilidade de emprego) estavam no emprego há mais de 5 anos, já, entre os trabalhadores que não tinham essa estabilidade, aproximadamente $60 \%$ das mulheres permaneciam apenas um ano no emprego enquanto aproximadamente $53 \%$ dos homens estavam nessa mesma condição; $82 \%$ das mulheres ocupadas no setor agricola não tinham rendimentos.

Em relação às doenças ocupacionais, Giannasi (1997) observa que há uma relação direta entre forma de organização da produção e o desenvolvimento dessas doenças, alertando que elas são provocadas por condições e organização do trabalho que, quanto mais precárias e intensas, maiores danos provocam. A intensificação dos ritmos e do conteúdo do trabalho, a racionalização da força produtiva, a busca por excelência, enfim, a polivalência tem sido a causa do considerável e alarmante número de casos de lesões por esforços repetidos. Aliam-se a essas questões, a inadequação dos postos de trabalho, a falta de pausas para descanso, a redução de intervalos de refeição/banheiro/banho, as longas jornadas de trabalho, o excesso de horas extras, o repouso insuficiente, - mobiliário desconfortável, as ferramentas e maquinarias inadequadas, a dupla ou múltiplas jornadas de trabalho, conjunto de fatores que contribuem para limitar ou incapacitar não só para o trabalho, mas para a vida como um todo, acrescenta a autora.

Araújo et al. (1999) apresentam dados que confirmam que tais doenças têm se desenvolvido em diferentes ramos industriais e atingido mais as mulheres do que os homens. Entre os trabalhadores com Lesões por Esforços Repetitivos ou Distúrbios Osteomusculares Relacionados ao Trabalho (LER/ DORT ${ }^{26}$, a porcentagem de mulheres acometidas era $86,7 \%$ no setor químico, $80 \%$ no setor bancário, $79,8 \%$ no setor metalúrgico. A explicação para o "sexo" da doença está relacionada com as atividades e postos de trabalho ocupados pelas mulheres. As autoras acrescentam que o discurso que associa a permanência das mulheres em ocupações que exigem paciência, atenção, higiene e sensibilidade, esconde as condições reais de trabalho a que elas estão submetidas (ritmo intenso, trabalho repetitivo, grande esforço físico, etc.) e os reflexos de tais condiçôes sobre sua saúde.

Em terceiro lugar, no que se refere à divisão sexual do trabalho, os estudos analisados apontam para uma tendência geral de permanência da ocupação dos cargos de acordo com concepções tradicionais de atributos masculinos e femininos. Entretanto, os dados também apontam para mudanças, entre as quais a elevação no número de mulheres que ocupam cargos hierarquicamente superiores, o aumento da participação de mulheres em ocupações tradicionalmente masculinas e de homens em ocupações tradicionalmente femininas.

Essas mudanças foram abordadas por Bruschini (2000) que compara 
dados da FIBGE, Censo Demográfico/Mão-de-Obra do ano de 1980 com os de 1991:

a) ampliação da participação feminina em ocupações administrativas (funções burocráticas ou de escritório, diretores e chefes de administração pública, chefes e encarregados de seção, administradores e gerentes de empresa, bem como empregadores): em 1980, num total de 5.101.926, havia 1.732 .153 mulheres, representando uma participação feminina nessas ocupações de $33,9 \%$; em 1991, do total de 7.704 .851 , havia 2.956 .588 mulheres, representando uma participação feminina de $38,4 \%$;

b) redução do número de mulheres ocupadas no setor têxtil (tradicionalmente feminino): em 1980, as mulheres representavam $60 \%$ (187.924) do total de ocupados (312.868), já em 1991, elas passaram a representar $49,4 \%$ (142.590) do total de ocupados (288.720);

c) aumento de aproximadamente $62 \%$ no número de mulheres mestres, contramestres e técnicas industriais (atividades tradicionalmente com baixa participação das mulheres): em 1980, havia 9499 mulheres nessas ocupações, representando $3,9 \%$ do total de ocupados; em 1991, elas passaram a representar $7 \%$ do total de ocupados, totalizando 15.359 mulheres nessas ocupações;

d) nas ocupações administrativas, tem se ampliado o número de mulheres empregadoras: em 1980, havia 107.066 mulheres nessa posição, representando $10,3 \%$ do total de ocupados desse grupo; em 1991, esse número passou para 346.926 , representando $17 \%$ do total de ocupados. Em números absolutos, esse aumento representa aproximadamente $220 \%$;

e) entre as ocupações técnicas, cientificas e artísticas ocorreu um aumento significativo do número de mulheres no período de 19801991: aumento de $170 \%$ para arquitetura (elas representavam $7,5 \%$ do total de ocupados e passaram a representar $12,2 \%$ desse total) e odontologia (elas representavam $28,6 \%$ do total de ocupados e passaram a representar $42,4 \%$ desse total); $146 \%$ para o jornalismo (elas representavam $25 \%$ do total de ocupados e passaram a representar $37,9 \%$ desse total); $126 \%$ na engenharia (elas representavam $4,4 \%$ do total de ocupados e passaram a representar $6,6 \%$ desse total); $144 \%$ entre advogados e defensores públicos (elas representavam $21,7 \%$ do total de ocupados e passaram a representar $30,4 \%$ desse total); $116 \%$ entre procuradores, promotores e curadores públicos (elas representavam $20,3 \%$ do total de ocupados e passaram a representar $30,8 \%$ desse total) e $300 \%$ entre os juizes (elas representavam $8,2 \%$ do total de ocupados e passaram a representar $19,8 \%$ desse total);

f) no setor financeiro, a participação feminina passou de $33,4 \%$ do total de ocupados (em 1980) para 40,3\% desse total (em 1991).

Ao comparar dados da FIBGE e PNADs $(1985,1995)$, verificamos a redução da participação feminina no setor de serviços (tradicionalmente 
feminino): em 1985, 32\% das mulheres ocupadas estavam nesse setor, passando para $29,8 \%$ em 1995. Esse espaço passa a ser ocupado pelos homens: 8,9\% dos ocupados masculinos estavam nesse setor em 1985, passando para $12 \%$ em 1995 (BRUSCHINI, 2000).

Percebemos uma ampliação da participação feminina em profissões consideradas como redutos masculinos (área técnica e cientifica, por exemplo), bem como a ampliação da participação masculina em setores tradicionalmente femininos (serviços, por exemplo), indicando mudanças na divisão sexual do trabalho.

Deve-se considerar que essas mudanças têm ocorrido pari passu a um processo de reprodução permanente das desigualdades de gênero. Os estudos de Hirata (1998) mostram que espaços que exigem maior qualificação e escolaridade têm sido ocupados pelas mulheres, incorporando-as em atividades antes consideradas masculinas. Mas, a autora (2002) observa a construção de um distanciamento profissional entre mulheres qualificadas e não qualificadas. Paralelamente à tendência de diversificação das funções femininas no mercado de trabalho, percebe-se a estruturação de uma situação bipolar - um pólo constituido por profissionais qualificadas/alto nivel de escolarização e bem remuneradas (engenheiras, arquitetas, médicas, professoras universitárias, gerentes, etc.) e outro formado por trabalhadoras "não qualificadas" que ocupam empregos mal remunerados e não valorizados socialmente (trabalhadoras domésticas e do setor informal, por exemplo).

Hirata (2002) mostra que, entre os empregos de serviço, a bipolarização é extremamente forte, pois com a crise e recessão dos anos noventa, desenvolveu-se na Europa, nos Estados Unidos e no Brasil, os chamados "empregos de serviço" ou "serviços de proximidade" (cuidado com crianças, idosos, doentes, trabalho doméstico remunerado, etc.) e, simultaneamente, desenvolveram-se novas profissões superiores do terciário. Isso reforçou a heterogeneidade do trabalho: as primeiras ocupações são associadas a trabalhos mal remunerados e de pouco prestígio social e as profissões de nivel superior passaram a representar um espaço de atuação feminina com reconhecido valor social.

Os "serviços de proximidade", ressalta a autora, podem acarretar conseqüências perversas do rebaixamento do estatuto já precário e desvalorizado dos empregos de serviço, sobretudo, "na medida em que tais modalidades de serviços são, regra geral, associadas ao feminino, dada a sua proximidade com o papel tradicional de 'relação de serviço' que as mulheres têm no interior da familia" (HIRATA, 2002, p. 348).

\section{Considerações finais}

A perspectiva de gênero tem permitido novas percepções sobre a realidade, abrindo possibilidades de análise e ajudando a compreender os impactos da globalização econômica e da reestruturação produtiva que têm se mostrado diferente quando se tratam de trabalhadores homens ou mulheres.

As diferenças entre homens e mulheres deixam de ser vistas como 
resultado de um "destino biológico" e passam a ser percebidas como diferenças social, histórica e culturalmente construidas num processo que envolve as relações de poder vigentes na sociedade. A divisão sexual do trabalho, uma das manifestações dessas relações de poder, também deixa de ser percebida como um processo natural que distribui homens e mulheres em atividades consideradas adequadas a seu sexo e passa a ser percebida como parte de relações sociais baseadas em diferenças socialmente construidas entre homens e mulheres.

A construção das identidades masculina e feminina ajuda a legitimar essa divisão por meio de atribuições de responsabilidades e tarefas diferenciadas para homens e mulheres. Nessa construção predominam posições desiguais, tanto na esfera da produção quanto no âmbito privado das relações familiares, sendo comum, em nossa sociedade, que a mulher seja responsabilizada pelas atividades reprodutivas e o homem seja percebido como o provedor da família. Se, por um lado, o trabalho produtivo faz parte da identidade masculina, por outro, a construção da identidade feminina condiciona e limita a participação da mulher no mercado de trabalho, principalmente devido à constante necessidade de articular atividades domésticas e profissionais.

No contexto global, os "novos" modelos de produção e organização empresarial têm ocasionado mudanças nas formas de produção e gestão com implicações e efeitos diferenciados para trabalhadores homens e mulheres. As mudanças têm afetado, sobretudo, o trabalho masculino, do qual se passa a exigir novas competências (técnica, capacidade para trabalhar em grupo, por exemplo), todavia, grande parte do trabalho feminino, particularmente 0 fabril, tende a permanecer organizado a partir do modelo taylorista em que as atividades são desenvolvidas de forma repetitiva, monótona e intensiva.

No que se refere ao trabalho feminino no Brasil, existe uma constante ampliação da participação feminina na população economicamente ativa; todavia, nas empresas brasileiras, a divisão sexual do trabalho tem contribuido para a manutenção dessas mulheres em posição desvantajosa, tanto em relação às condições de trabalho quanto em relação à valorização do trabalho.

$\dot{E}$ perceptivel, assim, a continuidade do processo de segregação (horizontal e vertical). As mulheres permanecem concentradas em postos de trabalho taylorizados, submetidas à organização e condições de trabalho que contribuem para o desencadeamento de um número elevado de doenças ocupacionais, principalmente de casos de lesões por esforços repetitivos. Vale destacar que, no mercado de trabalho brasileiro, há uma permanente reprodução das desigualdades salariais que favorecem os homens.

Existe uma continuidade da divisão sexual do trabalho pela qual as mulheres permanecem concentradas em ocupações tradicionalmente femininas. Todavia, verificamos uma tendência de alteração, pois ocorre uma ampliação do número de mulheres em cargos hierarquicamente superiores, a inserção feminina em atividades consideradas masculinas e a ampliação do número de homens em ocupações consideradas femininas.

Nas alteraçōes, destacamos a ocorrência da construção de diferenças entre trabalhadores do mesmo sexo (qualificados e não qualificados). Nesse sentido, destacamos a construção.da diferenças entre as mulheres, denominada 
por Hirata (2002) de bipolorização do trabalho feminino, no qual há um pólo composto por mulheres qualificadas, bem remuneradas e com prestigio social e, outro, formado por mulheres com baixa qualificação, mal remuneradas, sem prestigio social e, em grande medida, alocadas em trabalhos informais e precários.

1 Este trabalho faz parte da tese de doutorado "Reestruturação produtiva e gênero: um estudo de caso em duas empresas de linha branca", elaborada por Nanci Stancki Silva e orientada pela Profa. Dra. Leda Maria Caira Gitahy, cuja pesquisa foi desenvolvida como parte integrante do projeto comparativo internacional sobre a indústria de linha branca (International White Goods Project) coordenado pelo Professor Theo Nichools, da Universidade de Cardiff (Reino Unido), e realizado em seis países: Brasil, Grä-Bretanha, Turquia, Coréia do Sul, Taiwan e China. No Brasil, o projeto recebeu a denominação de "Globalização, estratégias gerenciais e respostas operárias: um estudo comparativo da indústria de linha branca". O projeto no Brasil foi coordenado pelas professoras doutoras Ângela Maria Carneiro de Araújo, Leda Maria Caira Gitahy, Alessandra Rachid, Adriana Marques da Cunha e contou com a participacão dos pesquisadores Nanci Stancki Silva, Ana Maria B. Pina, Daniel Perticarrari, Mariângela Martinez, Mariana Leite Figueiredo, Juliana Vieira Araújo e Rafael Gustavo de Souza. Essa pesquisa contou com o apoio financeiro do CNPq e FAPESP

2 Doutora em Política Cientifica e Tecnológica (UNICAMP); professora colaboradora do Programa de Pós-Graduação em Tecnologia e do Departamento Acadêmico de Matemática, da Universidade Tecnológica Federal do Paraná (UTFPR); pesquisadora do grupo de estudos e pesquisas sobre relaçōes de gênero e tecnologia (GeTec). E-mail: nancist@terra.com.br.

3 Doutora em Sociologia (Universidade de Upsala - Suécia); Professora do Programa de PósGraduação em Política Científica e Tecnológica - UNICAMP. E-mail: leda@ige.unicamp.br.

4 Entre os teóricos mais influentes dessa Escola, encontram-se M. Aglietta, Boyer e Lipietz (Larangeira, 1999).

5 O modelo japonês consagrou-se na década de 1980 como designação genérica de um conjunto de técnicas de organização da produção e do trabalho industrial, de práticas administrativas, relaçőes de trabalho e principios de gestão da empresa que estariam associados aos importantes ganhos de produtividade atingidos pelo sistema produtivo do Japão após a Segunda Guerra Mundial. (Xavier, 1997). Nessa década, segundo Wood (1993), o toyotismo, a japonização, o fujitsuismo, o ohnoísmo e sonyismo foram termos que entraram na sociologia do trabalho quando se faziam tentativas de refletir sobre a importância dos métodos japoneses. No cerne de cada um desses conceitos está um modelo de abordagem japonesa de gestão. Termos como ohnoismo e toyotismo são particularmente usados para indicar a inovaçăo da produção just in time. Baseados nos elementos básicos das práticas de fabricação japonesas, eles săo empregados tanto para caracterizar a forma organizacional dominante no Japão, quanto para denotar o modelo que se supőe estar atraindo cada vez mais os gestionários no Ocidente. O toyotismo poderia ser considerado ainda como um modelo de administração, a saber, a produção just in time, definido abrangentemente para incluir kanban e controle de qualidade total.

6 Destacamos que neste trabalho termos como especializaçäo flexivel, toyotismo, modelo japonês são usados para fazer referência às "novas" formas/modelos de organização do trabalho e da produçâo.

7 Essas três dimensões citadas por Hirata fazem referência ao trabalho de Philippe Zarifian (1999) intitulado de "Objectif compétence. Pour une nouvelle logique".

8 PNAD $=$ Pesquisa Nacional por Amostra de Domicilios.

9 As autoras consideram uma ocupação de baixa qualidade quando: não existe proteçăo, tem baixa remuneração, é de jornada parcial, tem escassas possibilidades de carreira e baixo nível de organização política.

10 Ocupação caracterizada por baixos niveis de rendimento, formalização e proteção da categoria, assim como presença de longas jornadas de trabalho.

11 Mulheres de todas as idades entram no mercado de trabalho, embora haja uma concentração para mulheres entre 30 a 39 anos.

12 As mulheres permanecem nos setores informais e desprotegidos do mercado de trabalho, seja no trabalho doméstico não registrado, atividade por conta própria, familiar não remunerado ou domiciliar.

13 Entre as caracteristicas destacam-se: a iniciativa, a responsabilidade e a capacidade de responder aos imprevistos.

14 Trabalho, em geral, monótono, repetitivo e com disciplina.

15 PME = Pesquisa Mensal de Emprego, realizada mensaimente pelo $I B G E$ em seis regiōes metropolitanas.

16 Antigos $1^{\circ}$ e $2^{\circ}$ graus.

17 Como exemplos desses cursos temos controle de qualidade, introdução à 1509000 . Os homens 
além dos cursos comportamentais também freqüentaram cursos técnicos para tarefas especificas, tais como eletricidade, computação, software, programação de máquina, inspeção.

19 Entre essas habilidades destacam-se destreza, perfeição na execução de detalhes e minúcia, paciência, docilidade, disciplina e maior resistência ao trabalho monótono.

20 Destreza, minúcia e precisão.

21 PEA é um indicador que reflete a parcela da população que está trabalhando ou procurando emprego (DIEESE, 2005).

22 Em 2003, as mulheres representavam 41,5\% das pessoas ocupadas (IBGE, PNADS 2003).

23 FIBGE = Fundação Instituto Brasileiro de Geografia e Estatistica.

24 Emprego em tempo parcial pode ser considerado como um regime de trabalho com menor número de horas e menor remuneração quando comparado com o trabalho em tempo completo, assim como pode representar uma forma distinta de emprego envolvendo condiçōes diferenciadas do tempo completo e uma segmentação do mercado de trabalho (Hirata, 1998).

O período analisado por Bruschini (2000) é de 1985 a 1995.

26 LER/DORT é um conceito que define um conjunto de doenças ou alterações funcionais que atingem: a região escapular, o pescoço, os ombros, os braços, os cotovelos, os antebraços, os punhos e os dedos. (Merlo, 1999)

\section{Referências Bibliográficas}

ABRAMO, Laís. Cambio tecnológico y el trabajo de las mujeres. In: Revista Estudos Feministas. Volume 5, $\mathrm{n}^{\circ}$ 1, Rio de Janeiro: Instituto de Filosofia e Ciências Sociais IFCS/UFRJ, 1997.

Inovação tecnológica e segmentação por gênero no mercado de trabalho. In: GITAHY, LEDA (org.) Reestruturaçión productiva, trabajo y educación en América Latina. Campinas: - IG/UNICAMP, Buenos Aires: RED CIID-CENEP, 1994.

Um olhar de gênero. Visibilizando precarizaçōes ao longo das cadeias produtivas. In ABRAMO, Lais e ABREU, Alice Rangel de Paiva (orgs.). Gênero e Trabalho na Sociologia Latino-Americana. São Paulo/Rio de Janeiro: ALAST, 1990.

ABREU, Alice Rangel de Paiva. O avesso da moda: trabalho a domicílio na indústria de confecção. São Paulo: Hucitec, 1986.

ARAÚJO, Ângela Maria Carneiro e AMORIM, Elaine Regina Aguiar. Redes de subcontratação e trabalho a domicilio na indústria de confecção: um estudo na região de Campinas. In: ARAÚJO, Angela Maria Carneiro. Cadernos Pagu: desafios da eqüidade. Campinas, no. 17/18, (2001/2002).

ARAÚJO, Ângela Maria Carneiro e GITAHY, Leda (2002/2003). Reestruturação produtiva e negociações coletivas entre os metalúrgicos paulistas. In: IDÉ|AS - Revista do Instítuto de Filosofia e Ciências Humanas, ano 9(2)/10(1). Campinas: UNICAMP, (2002/2003).

ARAÚJO, Ângela Maria Carneiro e OLIVEIRA, Eleonora Menecucci. Reestruturação produtiva e saúde no setor metalúrgico: a percepção das trabalhadoras. Texto mimeo, (sd).

ARAÚJO, Ângela M. C. et al. Globalização, estratégias gerenciais e respostas operárias: um estudo comparativo da indústria de linha branca. Relatório científico, Campinas, 2004.

As novas modalidade do trabalho feminino em tempos de flexiblização e reestruturação produtiva e seus impactos sobre a saúde da mulher trabalhadora. Trabalho apresentado no II Congresso Internacional Mulher, Trabalho e Saúde, Rio de Janeiro, 1999.

BEAUVOIR, Simone de. O Segundo Sexo (Fatos e Mitos, volume 1). Rio de Janeiro: Nova Fronteira, 1949.

BORGES, Ângela e GUIMARÃES, Iracema Brandão. A mulher e o mercado de trabalho nos anos 90: o caso da Região Metropolitana de Salvador. In: ROCHA, Maria Isabel Baltar da (org.). Trabalho e gênero: mudanças, permanências e desafios. Campinas: ABEP, NEPO/UNICAMP e CEDEPLAR/UFMG/ São Paulo: Ed. 34, 2000. pp. 111-138. 
BRITO, Jussara. Saúde, Trabalho e modos sexuados de viver. Rio de Janeiro: FIOCRUZ, 1999.

BRUSCHINI, Cristina. Gênero e trabalho no Brasil: novas conquistas ou persistência da discriminação? (Brasil, 1985/95). In ROCHA, Maria Isabel Baltar da (org.). Trabalho e gênero: mudanças, permanências e desafios. Campinas: ABEP, NEPO/UNICAMP e CEDEPLAR/UFMG/ São Paulo: Ed. 34, 2000. pp. 13-58.

Trabalho Feminino: trajetória de um tema, perspectivas para o futuro. In Revista Estudos Feministas. Volume 2, $n^{\circ} 3$, Rio de Janeiro: Instituto de Filosofia e Ciências Sociais - IFCS/UFRJ, 1994. pp. 17-32.

BRUSCHINI, Cristina e LOMBARDI, Maria Rosa. A Bipolaridade do trabalho feminino no Brasil contemporâneo. In: Cadernos de Pesquisa, $n^{\circ} 110$. São Paulo: Fundação Carlos Chagas, 2000. pp 67-104.

Médicas, arquitetas, advogadas e engenheiras: mulheres em carreiras, profissionais de prestígio. In: Revista Estudos Feministas. Volume 7 , números 1 e 2 . Florianópolis: Instituto de Filosofia e Ciências Sociais - IFCSIUFRJ: Centro de Filosofia e Ciências Humanas - UFSC, 1999.

BRUSCHINI, Cristina e UNBEHAUM, Sandra G. (org.). Gênero, democracia e sociedade brasileira. São Paulo: Fundação Carlos Chagas/Ed. 34, 2002.

BRUSCHINI, Cristina e PINTO, Céli Regina (orgş.). Tempos e lugares de gênero. São Paulo: Fundação Carlos Chagas. Ed. 34, 2001.

BRUSCHINI, Cristina e SORJ, Bila. Novos Olhares: mulheres e relaçōes de gênero no Brasil. São Paulo: Marco Zero/Fundação Carlos Chagas, 1994.

CARNEIRO, Sueli. Identidade Feminina. In: SAFFIOTI, Heleieth I. B. E MUÑOZ-VARGAS, Monica (orgs.) Mulher brasileira é assim. Rio de Janeiro: Rosa dos Tempos: NIPAS; Brasilia: UNICEP, pp.187-193, 1994.

CHESNAIS, François. A mundialização do capital. São Paulo: Xamã, 1996.

CONSONI, Flávia Luciane. Dez anos de estrutura de emprego na indústria automobilistica brasileira: rupturas e continuidades (1986/1995). Dissertação de mestrado apresentada ao Programa de Pós-Graduação em Politica Científica e Tecnológica, UNICAMP, 1998.

FIGUEIREDO, Vanessa Catherina Neumann. Stress e gênero: impactos da divisão sexual do trabalho em uma metalúrgica. Dissertação de mestrado apresentada ao Programa de Pós-graduação em Sociologia da Faculdade de Ciências e Letras da Universidade Estadual Paulista, Araraquara, 2000.

FRIGOTTO, Gaudêncio. A educação e formação técnico-profissional frente à globalização excludente e o desemprego estrutural. In: SILVA, Luis Heron (org.). A escola cidadã no contexto da globalização. Petrópolis: Vozes, 1998.

GIANNASI, Fernanda. A precarização do trabalho da mulher e seus impactos sobre a saúde. In: OLIVEIRA, Eleonora Menicucci de e SACAVONE, Lucila (orgs.). Trabalho, saúde e gênero na era da globalização. Goiânia, 1997.

GITAHY, LEDA (org.) Reestruturaçión productiva, trabajo y educación en América Latina. Campinas, SP-IG/UNICAMP/Buenos Aires: RED CIID-CENEP, 1994.

HIRATA, Helena. Reorganização da Produção e transformações do trabalho: uma nova divisão sexual? In BRUSCHINI, Cristina e UNDEHAUM, Sandra G. (orgs.) Genêro, democracia e sociedade brasileira. São Paulo: FCC/Ed. 34, 2002. pp 339-355.

Reestruturação produtiva, trabalho e relações de gênero. In Revista Latinoamericana de Estudos do trabalho: gênero, tecnologia e trabalho. São Paulo/Rio de Janeiro: ALAST, ano 4, $n^{\circ} 7,1998$. pp.5-27.

Da polarização das qualificações ao modelo de competência. In: FERRETI, Celso João [et al.] (orgs). Tecnologias, trabalho e educação: um debate multidisciplinar. Petrópolis: Vozes, 1994.

Sobre o Modelo Japonês: Automatização, Novas Formas de Organização e de Relaçōes de Trabalho. São Paulo: Universidade de São Paulo, 1993.

LAVINAS, Lena. Evolução do Emprego feminino nas áreas metropolitanas. In: ROCHA, Maria Isabel Baitar da (org.). Trabalho e gênero: mudanças, permanências e desafios. Campinas: ABEP, NEPO/UNICAMP e CEDEPLAR/UFMG/ Säo Paulo: Ed. 34, 2000. pp. 139-160.

LARANGEIRA, Sonia M.G. Fordismo e pós-fordismo. In: CATTANI, Antonio David. (org.) 
Trabalho e tecnologia: dicionário critico. Petrópolis: Vozes, 1997. pp. 89-93.

MELO, Hildete Pereira de. O feminino nas manufaturas brasileiras. In: MURARO, Rose Marie e PUPPIN, Andrea Brandão (orgs.). Mulher, gênero e sociedade. Rio de Janeiro: Relume Dumará. FAPERJ, 2001. pp. 124-136.

MERLO, Álvaro Roberto Crespo. Lesões por esforços repetitivos. In: CATTANI, Antoni David (org.). Trabalho e tecnologia: dicionário crítico. Petrópolis: Vozes, 1997. pp 143148.

MEYER, Dagmar Estermann. Gênero e educação: teoria e política. In: LOURO, Guacira Lopes; NECKEL, Jane Felipe e GOELLNER, Silvana Vilodre (orgs.). Corpo, gênero e sexualidade: um debate contemporâneo na educação. Petropolis: Vozes, 2003. pp. 927.

Sexualidade da mulher brasileira: Corpo e classe social no Brasil. Petrópolis: Editora Vozes, 1983.

OLIVEIRA, Eleonora Menicucci e SCAVONE, Lucila (orgs.). Trabalho, saúde e gênero na era da globalização. Goiânia: 1997.

POSTHUMA, Anne Caroline. Mercado de trabalho e exclusão social da força de trabalho feminina. In: ABRAMO, Laís; ABREU, Alice R. de Paiva (orgs). Gênero e trabalho na sociologia latino-americana. São Paulo. Rio de Janeiro: ALAST, 1998.

Mercado de trabalho e exclusão social da força de trabalho feminina. In ABRAMO, Lais e ABREU, Alice Rangel de Paiva (orgs.). Gênero e trabalho na sociologia latino-americana. São Paulo. Rio de Janeiro: ALAST, 1990. pp. 21-38.

RAPKIEWICZ, Clevi Elena. A Construção do gênero na Informática. Tese paresentada ao Programa de Pós-Graduação em Engenharia da Universidade Federal do Rio de Janeiro, Doutorado em Ciências em Engenharia de Sistemas e Computação, Rio de Janeiro, 1998.

RISEK, Cibela S. e LEITE, Marcia P. Dimensões e representações do trabalho fabril feminino. In: ABRAMO, Laís e ABREU, Alice Rangel de Paiva (orgs.). Gênero e trabalho na sociologia latino-americana. São Paulo/Rio de Janeiro: ALAST, 1990. pp. 63- 82.

SAGASTI, Francisco R. Knowledge and development in a fractured global order. In: Futures, volume 27, número 6, 1995.

SALERNO, Mario Sergio. Modelo Japonês, trabalho brasileiro. In: HIRATA, Helena (org.). sobre o modelo japonês: automatização, novas formas de organização e de relações de trabalho. São Paulo: Universidade de São Paulo, 1993.

SCOTT, Joan W. Gênero: uma categoria útil de análise histórica. In: Educação e realidade: Gênero e Educação. Volume 20, n² 2, jul/dez, 1995.

SEGNINI, Liliana Rolfsen Petrilli. Constantes recomeços: desemprego no setor bancário. In BRUSCHINI, Cristina e PINTO, Céli Regina (orgs.). Tempos e lugares de gênero. São Paulo: FCC: Ed. 34, 2001. pp. 143-183.

Desemprego, terceirização e intensificação do trabalho nos bancos brasileiros. In: GUIMARAES, Iracema Brandão. A mulher e o mercado de trabalho nos anos 90: o caso da Região Metropolitana de Salvador. In: ROCHA, Maria Isabel Baltar da (org.). Trabalho e gênero: mudanças, permanências e desafios. Campinas: ABEP, NEPO/UNICAMP e CEDEPLAR/UFMG/ São Paulo: Ed. 34, 2000. pp. 187- 210.

Educação, Trabalho e desenvolvimento: uma complexa relação - trabalho apresentado no I Workshop do projeto de pesquisa "Conceitos empregados na educação profissional" - NETE - Núcleo de Estudos sobre Trabalho e Educação - UFMG, 1998.

Relaçőes de gênero no trabalho bancário no Brasil. In: CASTRO, Nadya Araujo Castro e DEDECCA, Claudio Salvadore (orgs.). A ocupação na américa latina. São Paulo. Rio de Janeiro: ALAST, 1998a. pp. 231-244.

Relaçōes de gênero no trabalho bancário informatizado. In: Cadernos Pagu: gênero, tecnologia e ciência, $n^{\circ} 10$. Campinas: Núcleo de Estudos de Gênero/UNICAMP, 1998b. pp. 147-168.

. Aspectos culturais nas relações de gênero e a questão da produtividade em tempos de trabalho flexível e qualidade total. In: MOTTA, Fernado C. Prestes, CALDAS, Miguel P. (orgs). Cultura organizacional e cultura brasileira. São Paulo: Atlas, 1997.

A inserção da mulher no processo de difusão da automação bancária: questões para debate. In: GITAHY, LEDA (org.) Reestruturación productiva, trabajo y 
educación en América Latina. Campinas - IG/UNICAMP, Buenos Aires: RED CIID-CENEP, 1994. pp 247-269.

SILVA, Lorena Holzmann. Admitimos mulheres para trabalhos leves. In: Revista Estudos Feministas. Volume $3, \mathrm{n}^{\circ} 2$, Rio de Janeiro: Instituto de Filosofia e Ciências Sociais IFCS/UFRJ, 1995. pp. 349-363.

STEIN, Maria de Lourdes Tomio (2000). Gênero feminino no contexto do trabalho fabril: setor eletroeletrônico em Curitiba e Região Metropolitana na década de 90 . Dissertação de Mestrado apresentada no Programa de Pós-Graduação em Tecnologia do CEFET-PR. Curitiba, 2000.

XAVIER, Guilherme G. de F. Trabalho e tecnologia: dicionário crítico. Petrópolis: Vozes, 1997.

WOOD. Stephen J. Toyotismo e/ou japonização. In: HIRATA, Helena (org.) Sobre o "Modelo Japonês": automatização, novas formas de relaçóes de trabalho. São Paulo: Universidade de São Paulo, 1993. pp. 49-78. 